\title{
A „vaskalapos” kórboncnok rehabilitálása - száz éve hunyt el Genersich Antal (1842-1918)
}

\author{
Kiss László dr. \\ A szerző Egy „vaskalapos” kórboncnok lányai címü dolgozatának (Kiss L, Lacza T, Ozogány E. Zsinórpadlás. \\ Méry Ratio Kiadó, Somorja, 2013.) az Orvosi Hetilap számára átdolgozott irása.
}

\begin{abstract}
Aki hosszabb ideje foglalkozik az orvostörténelem kutatásával, előbb-utóbb rájön, hogy még a leghitelesebbnek tûnő adatokat sem lehet készpénznek venni. E sorok írója is tapasztalta már, hogy az orvos előd sírkövén található évszám egy évet téved az illető halálévét illetően. Még szigorúbbnak kell lenni a kortársak, hozzátartozók viszszaemlékezéseit illetően.
\end{abstract}

A verselés mellett a női lélek titkait is jól ismerő Füst Milán (1888-1967) írja Emlékezések és tanulmányok címú kötetében:

„Volt itt az orvosegyetemen sok évtizeddel ezelőtt egy kórboncnok professzor, Genersich nevű, aki különös ember volt. Különös és rendkívüli. Télen szalmával bélelte be csizmáját, és úgy járt az egyetemre, a női hallgatókat nem kedvelte, mert azt mondta, ez a tudomány nem való asszonyfajtának... A haladó szellemú orvosok vaskalaposnak, a tudomány kerékkötőjének nevezték őt. Én azonban néhány barátommal nagyon becsültem őt, többek közt azért, mert kitűnő stiliszta volt. Az ő meghatározásai valamely kóros szövet színéről, formájáról klasszikusok voltak, megmásíthatatlanok...” [1].

Füst véleményének (is) köszönhetőn az utókor Genersich Antalt az emancipáció ellenségei, a női nemet tudományos munkára alkalmatlannak vélők közt tartja számon. Sajnos - mea culpa! - én is „bedőltem” Füst sommás véleményének, és egy korábbi dolgozatomban [2] Genersich nőellenességére hivatkoztam Füst véleménye és az akkor még általam nem olvasott, „Lehetnek-e nők orvosok?” című Genersich-cikk címe alapján. Azóta sikerült az ominózus cikket megtalálni, és ez késztet most kórboncnokunk rehabilitálására, emlékének a nőellenességtől való megtisztítására.

Mielőtt tehát újraírnám Genersich és a nők kapcsolatáról szóló fejezetet, tekintsük át, hogyan is vélekedtek Genersich elődei, illetve kortársai a női nem orvosi (tudományos) pályára való alkalmasságáról.

Annak ellenére, hogy a sérültek ellátásában, a magatehetetlen betegek ápolásában, a szülés és a gyermekágy körüli teendők ellátásában a nők ősidők óta részt vettek, e tevékenységük magasabb szakmai szintre emelése és egyenrangúsítása a másik nem hasonló jellegű tevékenységével csak a XIX. században kezdődött meg. E kezdet nem volt könnyü. Az orvosi vagy gyógyszerészi oklevél megszerzése még a nálunknál fejlettebb és a nők emancipációja iránt nyitottabb nyugat-európai társadalmakban is rengeteg korlátba ütközött. E korlátok fenntartója még a XIX. század közepén is az a társadalmi felfogás volt, melyet frappánsan így fogalmazott meg BédySchwimmer Rózsa (1877-1948), a magyar feminista mozgalom egyik elindítója egy 1912-ben kiadott, a női „karrierekkel” foglalkozó könyv utószavában: „A világ elhitte, hogy a női nemnek csakis kizárólag két életcélja lehet: vagy szülni, vagy züllni” [3]. A nőknek azon törekvését, hogy a nemük miatt rájuk kiosztott anya-, illetve utcalány „szerepen” túl a másik nem által gyakorolt például orvosi - hivatásra is vállalkozhassanak, a férfitársadalom gyakran éppen a nói nemre, illetve a hozzá kapcsolódó évszázados előítéletekre hivatkozva utasította vissza. Ezen elöítéletek közül a nők gyöngébb szellemi képességeire hivatkozót húzták elő a leggyakrabban. Amikor Sophia Jex-Blake hat nőtársával 1870-ben először jelent meg az edinburgh-i orvosi kar előadótermében, a katedra előtt hét eleven birka ácsorgott, jelezve a férfi „kollégák” véleményét a „kolleginák” értelmi képességét illetően. Hiába volt a híres sebész és szülész - az éterrel, illetve kloroformmal végzett altatás egyik úttörője - Sir James Simpson támogatása, a „septum contra Edinam” (hetek Edinburgh ellen) bátor kiállása csak fél sikert hozott: Sophia és egyik társa kénytelen volt Svájcba költözni, hogy a berni egyetemen szerezhesse meg az orvosi oklevelet [4].

Nos, ennyire „látványos” és a nóket méltóságukban sértő ellenállásra nincs példa tájainkon, ám a monarchiabeli doktorok is sokáig csak mostohatestvérként kezelték Hippokratész lányait. Igaz, a nálunk felhozott érvek nem a női „alacsonyabb rendüségre” hivatkoztak; argumen- 
tálásuk a nemek közti pszichés és anatómiai eltérésekre épült. Még 1895-ben is, pedig ekkorra már a jég töredezni kezdett! Ekkor a vallás- és közoktatásügyi miniszter szakvéleményt kért a Magyarországi Gyógyszerész Egylet elnökségétől a nők gyógyszerészi pályára engedéséről. A derék testület a nők fizikai gyöngesége mellett azt is ellenérvként hozta fel, hogy „recept-titok megőrzésére csak kevesen lennének képesek" [5].

Ha sokan a lényegesen kisebb megterhelést jelentő és a nő számára jobban megfelelő gyógyszertári munkát sem „ajánlották” a „gyengébbik nem” számára, érthető, hogy még hangosabb volt a nők orvosi pályára engedése ellen ágálók tábora. Elsősorban a sebészet oktatói emelték fel szavukat a „nőorvosok” ellen. Osztrák „sógorainknál” egy jeles sebész, a cseh származású Eduard Albert (1841-1900) innsbrucki, majd bécsi professzor vallott „vaskalapos” nézeteket, különösen az 1895-ben kiadott $A$ nö és a medicina tanulása címü könyvével. Drámai hangú sorokkal indított: „Felemelem szavam a nők orvostudományi tanulmányai ellen... Már negyedszázada adok elő sebészetet ... ezer és ezer nőt figyeltem meg szenvedésükben és örömükben s felhasználtam minden alkalmat, hogy tudatosítsam alkatuk különlegességeit. A legjobb meggyőződésem szerint, ez az alkat az orvosi hivatásra nem alkalmas ... számomra a fizikai és pszichés alkalmatlanságuk kétségtelen...” [6].

Az emancipáció orvostörténeti vetületének „szelíd bája" az a tény, hogy végül mégiscsak a nők orvossá válását leginkább ellenző „véres szakma”, a sebészet volt kénytelen beadni a derekát és elfogadni a „nődoktorok” segítségét. Aszklépiosz (Aesculapius) gyógyító isten segítségére „kollégája” Arész (Mars) hadisten sietett. 1878-ban az Osztrák-Magyar Monarchia - a nemzetközi, berlini kongresszus beleegyezésével - megszállta Boszniát. A tartomány továbbra is a török szultán fennhatósága alatt maradt, de a kormányzás, a közigazgatás a közös pénzügyminisztérium „kezébe” került. Ennek fönöke Kállay Béni (1839-1903), a monarchia „közös pénzügyminisztere" felvilágosult, modern eszméket vallóként hamarosan rájött, hogy az okkupált „vad terület” gazdasági és szociális fellendítésének nagy akadálya a tartomány siralmas közegészségügyi állapota. Ennek egyik "legláthatóbb” jele a magas anya- és csecsemőhalandóság volt. Hátterében - a gazdasági elmaradás mellett - az állt, hogy a tartomány lakosságának több mint a fele $\mathrm{Al}$ lah híve volt, és a mohamedán vallás tiltotta, hogy nő férfi előtt - még ha az orvos is - mutatkozzék. Vagyis ha orvosi segítséget kíván eljuttatni a boszniai törökök közé, oda csak nőnemű orvost küldhet. Ezért Kállay pályázatot hirdetett egy Boszniában létesítendő orvosnői állásra [7]. Az állást lengyel, illetve cseh orvosnők töltötték be

Szomorú fintora a sorsnak, hogy Kállay felhívására elméletileg - jelentkezhetett volna magyar doktornő is: Hugonnai Vilma (1847-1922), akinek már 1880-tól volt Zürichben szerzett orvosi oklevele. Sajnos a Kállayfelhívás idején csak szülésznőként dolgozhatott. A rend- kívül múvelt, sokoldalú - ma úgy mondanánk - közíró, egyébként múvelődéstörténész, múfordító, kultúrpolitikus György Aladár (1844-1906), az emancipációért harcoló Mária Dorottya Egyesületben tartott előadásában - neve említése nélkül - így ecsetelte Hugonnai Vilma kálváriáját a Zürichből való hazatérése után: „...Midőn hazajött, tudori oklevelének érvényességét az intéző körök kétségbe vonták, mert egyetemi hallgatóvá érettségi oklevél nélkül lett. Az erős akaratú nő megtette, amit követeltek. Nehéz gondjai között tanult éjjel-nappal s letette az érettségi vizsgát sikerrel, bár még annyi kedvezményt sem engedtek neki, hogy a görög nyelvet ne tanulja. Áldozatkészsége nem aratott eredményt. Új és új követelésekkel léptek fel, s midőn késznek mutatkozott a budapesti egyetemen újból ismételni a tanfolyamot, a hatalom bírlalója kimondotta, hogy még így sem enged, mert elvből ellenzi, hogy Magyarországon nőorvos lehessen." György mégis optimistán zárta sorait 1891-ben: „Magyar orvosnő lesz bizonnyal, mert szükség van rá" [8]. Igaza lett: előadásának, illetve a Mária Dorottya Egyesület memorandumának és nem utolsósorban az orvosnők boszniai helytállásának köszönhetően az új kultuszminiszter, Wlassics Gyula 1895 szilveszterének napján kiadta a 72 029. sz. rendeletet, amely engedélyezte, hogy nők is látogathassák az egyetemek bölcsészeti és orvosi karát.

E rövid áttekintés után térjünk vissza Genersich Antalhoz. Mentségemre szolgáljon, hogy Füst véleményét Genersich „nőellenességéról” már említett [2] dolgozatom írásakor sem tudtam teljes mértékben elfogadni. Genersich emancipációellenességének ugyanis ellentmondott az a tény, hogy professzorunknak két lánya is az orvosi pályát választotta - vélhetóleg atyjuk beleegyezésével. Sajnos az idősebbik, Evelin a zürichi egyetem másodéves medikájaként hunyt el 1888-ban. A fiatalabb, Margit azonban 1902-ben már Pesten szerezte meg orvosi oklevelét, és később Hódmezővásárhelyen dolgozott szemészorvosként [9].

E tények ismeretében olvassunk bele az akkor még Kolozsvárott múködő Genersichnek egy helyi napilap, a Magyar Polgár hasábjain közzétett dolgozatába [10]. A cikk megírására egyébként - mint arra maga Genersich is utal - „Szilassy Kálmánné született gróf Hugonnai Vilma, zürichi orvostudor érettségi (!) vizsgához való bocsátását kérő folyamodványa adott apropót" (lásd fentebb!).

„Alig lehet kétség afölött, hogy egyéni szabadságunkat fóleg a civilisatio haladásának köszönjük, hogy sok bilincs... önmagától meglágyult és leolvadott” - indítja sorait Genersich. Egyike a még fennálló korlátoknak „az, mely a társadalom felét, a nóket, alsóbb rendú lényekként elzárja a magasabb, a szakszerü tudományos müveltség elől... E szokásnak észszerú alapja nincs..." szögezi le a kolozsvári egyetem már akkor tekintélynek örvendő kórbonctanprofesszora. A kérdés, tudniillik hogy érettségi vizsgára bocsáthatók-e, illetve megengedhető-e nekik az „itten (!) nyert vagy honosított orvostu- 
dori oklevél alapján az egyetemes orvosi gyakorlat - első rendben politikai kérdés" - véli Genersich. Ezzel mélyebben nem kíván foglalkozni doktorunk, szaktudásához húen inkább az „elvi” kérdésekre ad választ. Ama gyakori kérdésre, hogy a nők „testi szerkezetük és nemi életük" miatt alkalmasak-e az egyetemi tanulmányokra, igennel válaszol. Igenjét szakmája tapasztalatával támasztja alá: „A nő agya és férfi agy között lényeges különbség nincsen...” Mivel hazai tapasztalatokra nem hivatkozhat - hiszen Magyarországon az idő tájt még az érettségiig sem juthatott el a nő -, amerikai és angol „megbízható adatok” alapján leszögezi: „kétséget nem szenved, hogy a nő szellemi tehetségeit illetőleg magasabb mívelődésre képes”. Orvosként állítja, hogy „az egészséges és jól fejlett nő a havi változásokat elviseli... és az ivarvérzés ideje alatt is folytatja munkáját". Az ugyan igaz, hogy az „anyai functiok” (terhesség, szülés, kilencnapos gyermekágy) átmenetileg akadályozhatják a nőt orvosi munkája ellátásában, ám „ezen tény nem lehet indok arra, hogy a nő emiatt az orvosi gyakorlatra egészben képtelennek tekintessék". Arról nem is szólva - egészíti ki véleményét Genersich -, hogy nem is minden nő megy férjhez, mások korán özvegységre jutnak, $\mathrm{s}$ „mindezek... a tudománynak, az orvosi gyakorlatnak élhetnének". Genersich végül is így válaszolja meg a címben feltett kérdést: „....a szabályszerú vizsgák és elméleti s gyakorlati szigorlatok által eléggé biztosítva van az állam az iránt, hogy csak azok jutnának a gyakorlatra, kik valóban képesek erre..."

Miután a fentebb említett, 1895-ben kiadott rendelet megengedte a nók számára az egyetemi tanulmányokat, Genersich újra véleményt nyilvánított, a Magyarország címú budapesti lap hasábjain [11]. A lap közli, hogy az 1896/97-es tanévben négy hölgy - Schorr Matild, Steinberg Sarolta, Szendei Ida, Königsberger Lea - iratkozott be orvostanhallgatónak. Az új, 1897/98-as tanévben három újabb - Genersich Margit, Korach Regina és Curtiu Valéria - követte őket. Egyikük atyját, a közben Pestre költözött Genersich Antalt, „a budapesti egyetem nagytudományú professzorát" a lap meginterjúvolta. A tudósító természetesen az ominózus kérdéssel kezdi, melyre Genersich így válaszol: „Hogy a nók magasabb tudományos kiképzésre alkalmas észbeli tehetséggel bírnak, arra nézve elég tapasztalati tény hozható fel... nincsen semmi alap annak felvetésére, hogy ez a képesség nőknél éppen nem fordulna elő." A riporter azonban tovább okvetetlenkedik: véli-e a professzor úr, hogy a nők megszerzett tudásukat hasznosíthatják-e Magyarországon, „ahol az orvosok nagy része a megélhetéssel küzd"? Igaz, hogy a nagyobb városokban túl sok az orvos, és itt nehéz a megélhetés - ért egyet Genersich -, ám számos vidéki „állomás” évekig betöltetlen marad. „Valószínúleg tartom, hogy az orvosnőket különösen a nőbetegek s főleg a nóbajokban szenvedők fogják igénybe venni, s e tekintetben igen nagy szükség van azokra... Sokszor hiányos képzettségű bába vagy kuruzsló vénaszszonyhoz fordulnak, vagy orvossal kezeltetik ugyan ma- gukat, de a vizsgálatot megtagadják - argumentál tovább professzorunk -, ez az ellenszenv a vizsgálat s helyi kezelés ellen koránt sem lesz olyan nagy, ha az orvosi kezelést nók is végzik."

A „tudósító” nem hagyja magát, és belekapaszkodik Genersich utolsó mondataiba: „Eszerint a professzor úr az orvosnőket csakis nőorvosi gyakorlatra véli alkalmasaknak?" Erre még korai lenne válaszolni - kerüli ki a csapdát bölcsen Genersich -, majd így fejezi be nyilatkozatát: „Valószínú, hogy a közerkölcsiség nem lenne azáltal veszélyeztetve, ha a nőorvos beteg férfit gyógykezelne, amint is mostanig alig merült fel kihágás a közerkölcs ellen, mely onnan eredne, hogy egy férfiorvos beteg nőt gyógyított." Genersich szavait saját lánya igazolja majd, akiből nem nőgyógyász, hanem szemészorvos lesz, s így férfiakat is gyógyít.

E megnyilatkozások ismeretében úgy véljük, Füst Milán véleményét Genersich „nőellenességéről” nem fogadhatjuk el, ső́t ismerve tekintélyét a kolozsvári, majd a pesti egyetemen, Genersich Antalt az emancipáció, a nőorvosok képzése szószólójának tekinthetjük.

Az orvostörténész számára pedig egyértelmú a tanulság: a nekrológokban, emlékezésekben felbukkanó állításokat, véleményeket fenntartással lehet csak elfogadni.

\section{Irodalom}

[1] Füst M. Memoirs and studies. [Emlékezések és tanulmányok.] Második kiadás, Magvető Kiadó, Budapest, 1967. [Hungarian]

[2] Kiss L. Female medical students in the servants' entrance, or medical history curiosities from the Hungarian history of emancipation. [Medikák a cselédbejáróban, avagy orvostörténeti kuriózumok az emancipáció magyarországi történetéből.] Lege Artis Med. 2009; 19: 358-360. [Hungarian]

[3] Bédy-Schwimmer R. Epilogue. In: Szikra (ed.) The life of great women. [Epilóg. In: Szikra (szerk.): Nagy asszonyok élete.] Singer és Wolfner, Budapest, 1912; pp. 209-235, idézve: 227. [Hungarian]

[4] Brooke E. Women healers - through history. The Women's Press, London, 1993; p. 116.

[5] Péter HM. Women as pharmacists. Hungarian relations of Transylvanian pharmacy. [Nők a gyógyszerész pályán. Az erdélyi gyógyszerészet magyar vonatkozásai.] Erdélyi Múzeum-Egyesület. Kolozsvár, 2002. [Hungarian]

[6] Rychlík AJ. First Czech doctoresses. [První české lékařky.] Zdravotnické noviny, Praha; 1980. 9. 25. [Czech]

[7] Steinberger S. History of doctoresses. [Az orvosnők törénete.] Orv Hetil. 1902; 46: Gynaekologia, pp. 124-125. [Hungarian]

[8] György A. Women as doctoresses. [Nők mint orvosok.] Gyógyászat 1891; 30: 466-469. [Hungarian]

[9] Györffy I. Biographical database of the most significant oculists in Hungary in the twentieth century. [A XX. században múködött jelentősebb Magyarországi Szemorvosok Életrajzi Adattára.] Magánkiadás, 1987; p. 58. [Hungarian]

[10] Genersich A. Could women be doctors? [Lehetnek-e nók orvosok?] Magyar Polgár (Kolozsvár), 1880. 4. 18. [Hungarian]

[11] Genersich A. Women as doctoresses. [Nők az orvosi pályán.] Magyarország, 1897. 9. 15. [Hungarian]

(Kiss László dr., SK-93 008 Csilizradvány 284., Szlovákia e-mail: kiss.agi@panelnet.sk) 